\title{
Nibbanic (or Pure) Consciousness and Beyond
}

\author{
David Woodruff Smith
}

Received: 30 January 2011 / Accepted: 23 February 2011 /

Published online: 15 March 2011

(C) The Author(s) 2011. This article is published with open access at Springerlink.com

\begin{abstract}
Pike's phenomenology of mystical experiences articulates sharply where theological content may enter the structure of Christian mystics' experiences (as characterized in their own words). Here we look to Buddhist (and other) accounts of "pure" or "nibbanic" consciousness attained in experiences of deep meditation. A contemporary "modal" model of inner awareness is considered whereby a form of pure consciousness underlies and embraces further content in various forms of consciousness, including mystical experiences in different traditions and experiences of "full union" (with God).
\end{abstract}

Keywords Consciousness · Inner awareness · Intuition · Mindfulness · Modal model (of consciousness) - Mystic union $\cdot$ Mystical experience $\cdot$ Nibbanic consciousness · Pure consciousness $\cdot$ Phenomenography

\section{Prolegomena: Pike's Project}

Nelson Pike's final phase of work produced his richly contoured book, Mystic Union: An Essay in the Phenomenology of Mysticism (1992). It is fitting that he published the book with Cornell University Press, for Nelson was already studying the phenomenology of mystical experience when he taught at Cornell in the 1960s (as Marilyn McCord Adams told me in conversation).

Mystical experience includes a variety of exceptional forms of consciousness. In many characterizations, the meditator experiences a kind of "pure" consciousness, as the objects of everyday consciousness leave the scene and the sense of self also leaves the scene, resulting in an experience of pure consciousness without any sense of either subject or object. In ancient Buddhist terms this form of consciousness is associated with nibbana or nirvana. "Nibbana" is the Pali term used in the original Buddhist canon, a variation on the older Sanskrit "nirvana".

Presented informally at the Nelson Pike Conference at the University of California, Irvine, on December 11, 2010.

Forthcoming in an issue of Philosophia (edited by Asa Kasher) devoted to the work of the late Nelson Pike.

D. W. Smith $(\bowtie)$

Department of Philosophy, University of California, Irvine, CA, USA

e-mail: dwsmith@uci.edu 
Popular images of "nirvana" are surely far from the experience achieved in deep meditation. I should like to use the term "nibbanic consciousness" for that basic form of awareness described in accounts of deep meditative consciousness and ultimately peak mystical experiences. ${ }^{1}$

Pike's concern is a specific form of consciousness wherein the Christian mystic experiences what she/he describes as a union with God. Pike's phenomenology of that form of experience proceeds by a careful study of classical accounts recorded in writing by a series of mystics in the Christian tradition. How can we map out the structure of experiences of nibbanic consciousness? How does the experience of union with God take shape within that structure, given that both subject and object have disappeared in the mystic's consciousness? These are the issues we shall address.

The approach I should like to take here to Pike's sensitive analyses of mystical experiences is two-fold. First, I should like to tie Pike's conception of phenomenological analysis into the broad practice of phenomenology initiated by Edmund Husserl. Second, I should like to consider a particular model of consciousness that offers a structure which, on reflection, allows for nibbanic consciousness. That model I've called the "modal" model of (self-) consciousness. We note immediately that the particle "self-"here does not allude to the subject "I" (the self that is said to disappear), but rather to the awareness-of-experience that is held to be intrinsic to consciousness per se. ${ }^{2}$

\section{Phenomenology and Phenomenography: Pike's Methodology}

Phenomenology is the study or analysis of consciousness - of particular forms of conscious experience-as experienced from the first-person perspective, that is, from within consciousness (allowing for "self-less" forms of consciousness). In the broad style inaugurated by Husserl, we reflect on a familiar form of experience, developing a phenomenological description (or analysis) of that type of experience. I see a tennis ball bouncing toward me. Here I have a familiar form of experience, one I have often lived through. Reflecting on what it is like to have this experience, I produce a simple phenomenological description:

I see this yellow bouncing tennis ball coming toward me, and I turn toward it and start to swing my racquet to meet it.

Of course, a much more interesting and detailed description is appropriate, addressing sensation, conception, kinesthetic-proprioceptive bodily awareness, and volitional movement-all in the complex flow of consciousness as I play tennis. For our purposes, however, this simplified description begins to articulate various

\footnotetext{
${ }^{1}$ I borrow the term "nibbanic consciousness" from Miri Albhari's insightful study: Analytical Buddhism: The Two-Tiered Illusion of Self (2006). Albahari's focus on nibbanic consciousness, in the classical Theravada Buddhist tradition, evolves through studies of consciousness arising in current analytic philosophy of mind. Her results are amenable in my eyes to analytic phenomenology. Thus her title is apt. The term "nibbanic consciousness" indicates, to my ear, a phenomenon that deserves its own special name. "Pure consciousness" is suggestive, and I shall often use it in apposition, but it may not naturally indicate this specific phenomenon. Compare the studies in Robert K. C. Forman (editor), The Problem of Pure Consciousness: Mysticism and Philosophy (1990).

${ }^{2}$ Here see a series of studies: Smith $(1986,1989,2004,2005)$.
} 
features of my conscious visual and enactive experience amid a point in a game of tennis. ${ }^{3}$

This broad approach to phenomenology fits Pike's project, announced in the subtitle of his book, "An Essay in the Phenomenology of Mysticism". But now the practice gets interesting. If Nelson or you or I have never experienced a bona fide mystical experience, then how can we get going in an analysis of the form of mystical experience as experienced from the first-person perspective?

Pike's practice is to study the actual first-person reports of a number of mystics. His phenomenology of mystical experience thus proceeds by articulating a phenomenological description drawn from the other's first-person perspective on her/his mystical experience. Pike calls this practice phenomenography.

Interestingly, Husserlian phenomenology provides the tools to amplify Pike's methodology here. Indeed, following the style indicated above, we observe that classical phenomenology proceeds by developing phenomenological descriptions of experience-how else? - in words: in language, communicating to others what the first-person form of experience is like in a given case, even if others have not experienced precisely that form of experience. Accordingly, Pike's conception of phenomenography aptly fits the style of analytic phenomenology, which pays close attention to the language of phenomenological description and, if you will, its logic. ${ }^{4}$

But there is more. One of the richest pieces of phenomenological analysis Husserl developed was his account of empathy (Einfühlung). ${ }^{5}$ When I see the anger in your face, I understand how you feel, instinctively by empathy. When I see that you see the tennis ball flying toward my backhand, I understand what it is like for you to see that ball from your spatiotemporal perspective. The first-person perspective begins with one's sense of location: "I" am "now here" as I see the tennis ball in flight, moving my eyes, head, torso, feet as I address its arrival. But not only do I experience the ball's flight from my visual perspective. I also experience it as "there for you", that is, as it would appear from your visual perspective on the other side of the net. I experience my seeing the ball; you experience your seeing the ball. And in empathy $I$ experience your seeing the ball: not actually from your own perspective (with your own eyes), but from my deferred perspective as if I were in your tennis shoes (with your eyes moving well above your shoes). I sense empathically how you seem to be seeing the ball's flight. That is, in my empathic perception of your seeing the ball, I grasp intuitively what it is like for you to see it from your perspective.

Now, I should like to propose, the practice of phenomenology itself always essentially involves empathic apprehension of the form of experience articulated in a

\footnotetext{
${ }^{3}$ Husserl developed a specific methodology for studying consciousness as experienced: the famous method of epoché or bracketing. I bracket, or put aside, the question of the existence of the object I (seem to) see, and thereby focus instead on my experience (as if) of that object. Here we may assume a simplified account of the practice. See Husserl, Ideas I (1913/1983) and Ideas II (1912/1989). See Smith (2007) for a contemporary reconstruction of Husserl's conception of phenomenology and its methodology.

${ }^{4}$ This style of phenomenology is elaborated in Smith and McIntyre (1982) and in Smith (2007). This way of doing business in phenomenology is sometimes called analytic phenomenology. Its style is influenced by the seminal work of Dagfinn Føllesdal, who works in logical theory as well as Husserlian phenomenology. Husserl's conception of transcendental phenomenology is developed in Husserl, Ideas I $(1913 / 1983)$ and Ideas II (1912/1989).

${ }^{5}$ See the rich account of empathy and intersubjectivity in Husserl, Ideas II (1912/1989).
} 
given phenomenological description! When I produce a description of the form of experience I am living through, my description allows you to grasp what that form of experience is like. When Husserl or Merleau-Ponty produces a description of a perceptual experience ("I see the woolly yellow of the tennis ball at my feet"), the point is to bring out to anyone what that form of experience is like. If anyone were to have that form of experience, that is what it would be like for her.

So phenomenology in practice naturally proceeds by phenomenography.

The situation with mystical experience is, to be sure, much more challenging. It is difficult to describe to a sightless person what it is like to see red as opposed to blue (red is "warm", blue is "cool"?). It is still more difficult to describe to the everyday person, busy with everyday life, what it is like to have a mystical experience. That is why Nelson Pike's book is so remarkable, exploring the mystic's own poetic descriptions of her experience. The mystic describes her mystical experience in rich detail. But this phenomenological description is produced in retrospect. That retrospective perspective is itself in effect an empathic apprehension. If I am the mystic, I now tell you what it was like for me then to experience "pure" consciousness. In retrospect, and in phenomenological description, the present "I" projects itself empathically into the perspective of the past "I". Yet this empathic apprehension at a distance - within the same stream of consciousness - finds that the sense of "I" disappeared in the prior experience. To be exact, then, this present retrospective experience projects consciousness (ostensibly sans self) from this present phase into that past phase of consciousness (sans self).

And so the phenomenological description proceeds: characterizing the sense of that prior state of consciousness now "for anyone" to grasp. Already, we see that the phenomenological structure "I" is minimally, as Husserl emphasized, a "zero point" of orientation in occurrent consciousness, not yet an object, a substantial mental or spiritual substance. But here we get ahead of our story.

\section{Factors of Consciousness: The Modal Model}

Consider, more closely, my prosaic experience of seeing a tennis ball advancing upon me, challenging my backhand stroke.

The phenomenological form of my experience can be factored into several distinct and distinctive features. What am I conscious of? This ball approaching, this yellow, bouncing tennis ball. What species of experience presents this ball? Visual perception. I see the ball. (I also hear its bounce on the court, but that is another slice of my total consciousness.) When and where does the ball appear visually? Now, in the present phase of the flow of events including my stream of conscious activity. Here, in relation to my own moving body. And to whom does the ball now here visually appear? To me. I now here see this ball. (My opponent also sees the ball approaching me, but that visual appearance is to him.) In what context of experience does all this occur? In my current phase of consciousness. In this very experience I now here see this ball. And is all this appearingexperientially, phenomenally_in my experience? Yes. Phenomenally in this experience I now here see this yellow, bouncing ball. That is what it is like to experience this act of consciousness! 
We have just constructed a basic phenomenological description of my experience:

Phenomenally in this very experience I now here see this yellow, bouncing tennis ball (as I move about to strike it with my racquet).

This analysis of phenomenological structure articulates what I have called the modal model of (self-) consciousness. ${ }^{6}$ In that analysis we factor the structure of the experience into several different characters. The mode of presentation in the experience is that of the content $<$ this yellow, bouncing tennis ball ...>. A categorially distinct part of the structure of experience is the modality of presentation, that of the "modal" content < phenomenally in this very experience I now here see>. Where the mode of presentation concerns the way the object of consciousness is experienced, the modality of presentation concerns the way(s) the act of consciousness is executed. ${ }^{7}$

Within the modality, then, we have factored out several importantly different characters of the experience:

$<$ phenomenally $>$, marking the phenomenal character of the experience, or what it is like as it "appears" in consciousness;

$<$ in this very experience $>$, articulating the reflexive self-intimating character of the experience;

$<\mathrm{I}>$, defining the egocentric or subject-oriented character of the experience as enacted by the subject;

$<$ now $>$, defining the temporally present character of the experience as unfolding in the stream of consciousness;

$<$ here $>$, defining the spatially orienting character of the experience with respect to the "lived" body of the subject;

$<$ see $>$, defining the species of experience, including here the sensuous character of the experience.

Of particular interest is the modal character < phenomenally in this very experience>. On the modal model, this character defines the form of inner awareness of the experience.

A central thesis in the theory of consciousness is the principle that a conscious mental act includes a pre-reflective form of self-awareness, or "inner awareness". ${ }^{8}$ In classical phenomenology, leading from Brentano into Husserl into Sartre, this form of awareness is constitutive of consciousness. As Sartre put it, self-consciousness (conscience de soi) is constitutive of consciousness itself (conscience): to be conscious of some object is eo ipso to be conscious of that consciousness. The core of this thesis takes shape in a variety of philosophical theories. What the modal model proposes is a particular form for that "self-awareness" without which mental

\footnotetext{
${ }^{6}$ See Smith (1986, 1989, 2004, 2005).

7 The terms I use here echo logical notions: Frege's notion of Sinn as carrying a "mode of presentation" or manner of being given in consciousness, and of course Husserl's notion of noematic Sinn; Hintikka's notion of intentional "modalities" including belief, perception, et al. See Smith and McIntyre (1982) on the semantic affinities of phenomenological notions. The "modal" characters include what Husserl called ways-of-givenness (Gegebenheitsweise), such as visuality, attentiveness, temporality (horizonal) - though Husserl's treatment of these characters was not particularly well-structured, and of course the Hintikkian notion of intentional modalities was decades away.

${ }^{8}$ A variety of approaches to this thesis are studied in the essays gathered in Kriegel and Wiliford (eds.) (2006).
} 
activity is not conscious. Again, the "self-" of this "self-awareness" is not the subject "I", "my-self", but simply the experience, "it-self". Indeed, in one ancient Indian view the original "self" is said to be consciousness (itself). ${ }^{9}$ And in European philosophy the "self" is dissolved into experience in the theories from Hume to Sartre.

Is there a way of understanding this character of inner awareness whereby we may specify the form of nibbanic consciousness? I should like to propose just such an interpretation.

\section{Nibbanic (or Pure) Consciousness: Awareness sans Object, sans Subject, sans Intentional Content}

The modal model above factors out of a familiar form of visual consciousness the form of inner awareness: < phenomenally in this very experience $>$. Phenomenality is the character of experience "appearing" in consciousness - as we say, "phenomenally". The metaphor of "luminosity" is ancient and suggestive, as if all experience begins with appearance in the light of consciousness. ${ }^{10}$ No light, no consciousness, period. Reflexivity is the self-intimating character of experience. "In this very experience", or simply "herein", an experience or phase-of-experience appears, in the light. That is, the experience is in this minimal, reflexive way articulated as "this experience". No reflexivity, no experience in the light. The fusion of these characters defines the inner awareness that renders any experience conscious, that is, a unit or act of consciousness. So goes the analysis.

Now, in the everyday experience appraised above, the character of inner awareness qualifies the intentional structure of a simple visual experience: an experience wherein a subject is directed toward an object via a certain content, in a visual species of mental activity, localized temporally in the stream of consciousness and spatially in the embodied subject in that activity. "I now here see this ... ball": inner awareness renders this form of mental activity conscious. But what happens to the familiar subject-object structure-or, more fully, the subject-act-content-object structure-in experiences of deep meditation?.

According to classical phenomenological-phenomenographic-reports through the ages: In sustained meditation the sense of object disappears, i.e. the intentional content or object-specifying sense disappears, and the sense of self or subject disappears. ${ }^{11}$ That is to say, the usual intentional structure of subject-object-or subject-act-content-object-dissolves in such a meditative state. ${ }^{12}$ There is then just this flowing phase of consciousness. Even the normal species of activity, such as

\footnotetext{
${ }^{9}$ See Gupta (2003), page 100 .

${ }^{10}$ See MacKenzie (2007) on this ancient Indian theme in relation to current Western models of the sort here in the background. MacKenzie focuses on the difference between "reflectionist" (higher-order) and "reflexivist" (self-illuminating) models. See Gupta (2003), page 100-101, on consciousness as "self" and "self-luminosity" on one view in Indian philosophy.

${ }^{11}$ Just two contemporary accounts of this experience, drawn from the Buddhist tradition, are Goldstein (2003) and Albahari (2006), the former practical and the latter theoretical. See also the varied essays in Walsh and Vaughn (eds.) (1993), emphasizing a "transpersonal" perspective in contemporary practices of meditation and psychotherapy.

${ }^{12}$ I assume, here and above, the broad model of intentionality developed by Husserl in Brentano's wake. This conception of intentionality is detailed in Smith and McIntyre (1982) and again in Smith (2007).
} 
seeing, disappears, as the practice is to refrain from these forms of activity that carry attention or "intention" from subject to object. Also disappearing is the sense of temporal and spatial location in the surrounding world (the external "horizon" wherein the subject is normally acting) or in the given stream of consciousness (the internal "horizon" wherein the subject's personal identity takes shape). ${ }^{13}$ What remains in consciousness is then, we may say, the form of nibbanic or pure consciousness. The experience that then appears or transpires is a state or process of "pure" consciousness: sans object, sans subject, sans intentional content, and sans worldly context. ${ }^{14}$

This meditative experience is phenomenal: it is appearing, "phenomenally", in consciousness, and what it is like is simply one of being conscious, as if awaiting what else may or may not appear in consciousness. And this meditative experience is reflexive: it is appearing "herein", "in this very (phase of) experience", selfarticulating as simply "this experience". The experience is one of pure awareness, inner awareness - not yet an awareness by "me" of some "object".

Importantly, this form of meditative experience is not itself reflective. It does not reside in a form of reflection on itself, a kind of higher-order self-monitoring. ${ }^{15} \mathrm{Such}$ an experience of observation may join the experience. Indeed, such a form of observant self-awareness is the goal of the practice called "mindfulness" or vipassana in one Buddhist tradition and similarly "witness-consciousness" in an Advaita Vedanta tradition. ${ }^{16}$ In this practice the meditative experience prepares for an experience of consciousness per se-pure awareness, as it were-and allows then for noticing particular thoughts, feelings, or sensations that may come along in the stream of consciousness.

If the modal model is on track, then the primary form of consciousness, isolated by the meditative practice, is the basic form of experience: <consciously $>$, or $<$ phenomenally herein $>$, $<$ phenomenally in this very experience $>$. This is the basic form of nibbanic consciousness. Settling into this nibbanic state is achieved by various meditative techniques practiced, often beginning by focusing attention solely on one's breathing. The fact that further states of consciousness may join or intrude on this pure consciousness, as particular thoughts or feelings pass by, shows that the base consciousness is indeed distinct from the whole conscious experience wherein, say, consciously I now here see this yellow, bouncing tennis ball. The practice of

\footnotetext{
${ }^{13}$ Here I am adapting Husserl's notion of the horizon of an act of consciousness, both "internal" and "external" horizon. See Smith and McIntyre (1982) for a reconstruction of the Husserlian notion of horizon, and again Smith (2007).

${ }^{14}$ This sketch is but a gloss of varying forms of meditative experience, which have been described and analyzed with much complexity. Goldstein (2003) describes (and prescribes) contemporary practices of "insight meditation" following Buddhist meditative practice today. Albahari (2006) analyzes the classical Theravada Buddhist "no-self" account of consciousness. Mohanty (1993) studies theories in Indian philosophy in relation to $20^{\text {th }}$ century Husserlian phenomenology. Gupta (2003) studies key issues as they develop from the Upanishads through Buddhist philosophy into Advaita Vedanta and more, with an eye to phenomenology. Many authors writing in Walsh and Vaughn (eds.) (1993) characterize meditative experiences in contemporary practices.

${ }^{15}$ The studies in Kriegel and Wiliford (eds.) (2006) distinguish varieties of theory about how a mental state may or may not be monitoring itself, in higher-order or same-order or self-representational or reflexive forms of monitoring.

${ }^{16}$ See Gupta (2003), pp. 108ff., on witness-consciousness; Goldstein (2003), p. 37, on vipassana; Smith and Novak (2003), pp. 74-87, on details of vipassana (more thereon below).
} 
meditation allows these familiar subject-object forms of experience to flow along while basic nibbanic consciousness remains what it is.

In the normal case of everyday experience, inner awareness is experienced only as a proper part, and a dependent part, of the experience: as in consciously seeing the ball. Meditative experience, by contrast, leads into an experience of pure or nibbanic consciousness. Then, extending the meditative practice, witness-consciousness ensues: wherein there is not only the base (nibbanic) consciousness but also, as observed, a passing thought or feeling in consciousness. The practice enables us to experience and separate the several factors of everyday experience, sensing the form of pure or nibbanic consciousness apart from its usual role in conscious subjectobject experience.

Where does this take us in addressing Pike's phenomenology of mystical experience? Pike's perceptive analysis opens the door to our approach here.

\section{Mystic Union: Nibbanic Consciousness with a Sense of Transcendence}

Mystical experiences seem to vary across different traditions and times. At least the reports of such experiences seem to vary.

Sometimes the experience is described as a sense of "nothingness" or of an "abyss". That means, I take it, no object and no subject is appearing in consciousness: consciousness in this form is not intentional, directed from a subject toward an object, yet it is a consciousness. Particularly striking are the Buddhist accounts of this "no-self" form of experience: the "self" is found to be an illusion or, more precisely, an intentional projection or construction not properly found in pure consciousness per se. ${ }^{17}$ Interestingly, fragments of these phenomenological themes recur in Western philosophy quite apart from meditation and mysticism. Hume famously said he could find in his experience no "self" (this thing I call "myself"), but only a sequence of "perceptions". Similarly, Sartre famously held that consciousness has no "I" or "ego" (a "subject" from which consciousness aims toward its object), whence the "self" is an "object" that appears only in reflection. In any event, our concern here is the phenomenology of mystical experience.

At the other end of the phenomenographic spectrum, mystical experience is variously described as producing a sense of the oneness of all being, a sense of "wholeness", as it were, "all-ness". Thus, the mystic characterizes her experience as achieving a union with Being itself, or the Brahman (= Divinity), or The One, or the Godhead (= Godhood), or simply God! We might say, neutrally, that mystical experience brings a sense of transcendence, a sensibility which may or may not open into a more conceptually framed sense of "God".

Odd as it sounds, "nothingness" merges with "allness". For the experience of "nothingness" is a sense of "no-thing-ness", and therewith "the one" realm of being, experienced without the differentiations that define particular "things" including "self" and "object". 18

\footnotetext{
${ }^{17}$ See the analysis of these themes in Albahari (2006).

18 Relevant and varied characterizations of "transpersonal" meditative experience, ranging from "self-lessness" to "nothingness" to "wholeness", are developed in numerous essays in Walsh and Vaughn (eds.) (1993).
} 
How does God enter the phenomenology of mystic union-where, it is reported, the sense of self and the sense of object have disappeared? How can the mystic's experience present a union of herself with God if her experience does not include a consciousness of either subject (herself) or object (God) in the experience of union? And, moreover, how will her tradition's theological conceptions affect her experience of mystic union? The narrative arc of Nelson Pike's book leads into just these questions.

Pike's concern is specifically Christian mysticism. His phenomenography uses richly expressed quotations from a variety of Christian mystics, featuring Saint Teresa especially, but using other Christian mystics' quotations to sometimes contrast with Teresa's account. These quotations must be read slowly and meditatively on their own, affording an empathic phenomenology of the experiences described (to the best of our ability and perspective).

Pike's phenomenography analyzes proto-typical Christian mystical experience as unfolding in characteristic phases, described in the first half of Pike's book (Chapters 1-4). The second half of the book (Chapters 5-8) addresses the problem of how to appraise a theistic form of mystical experience. In the final chapter, drawing on his prior results, Pike presents his own phenomenology (or phenomenography) of the experience of "mystic union" (Chapter 8).

On Pike's sensitive interpretation (pp. 159-160), the mystic describes experiences in deep contemplative prayer wherein she experiences distinct forms of "union with God"- distinctive forms of transcendence (if I may import that term):

- Prayer of Quiet - where she feels a sense of closeness to God "in here";

- Prayer of Full Union-where she experiences "union" with God;

- Rapture - where she experiences a "peak experience" of "union";

- Union Without Distinction-where in "union" the sense of "self" has vanished.

(See pp. 38-39, 208ff, on this latter form of mystical experience.) As an approximation, these forms of consciousness seem to define a gradation of consciousness increasingly moving into communion with God. Another form is that of love as "spiritual marriage", where, for Teresa, a sense of God as "lover" and "mother" is experienced.

On Pike's construction, these forms of experience unfold in temporal sequence, where the sense of Quiet leads into the sense of Full Union, which leads into the sense of Rapture, which leads into the sense of Union Without Distinction. However, the mystic may experience Quiet without Full Union or Rapture, or without a sense of Union-without-Distinction. Accordingly, I should like to propose an analysis of levels of consciousness (in due course below). This analysis has the advantage of allowing commonalities between different mystical traditions, while making room (per Pike) for theistic and specifically Christian forms of mystical experience.

Along the way, Pike expands richly on fine points of interpretation. Let me cite just a couple of key points, which fit well with the themes raised in our account of "pure" consciousness.

First, Teresa describes the role of her "soul" in these experiences, as if her soul is moving about in her "interior castle" as she comes into closer and closer communion with God. (pp. 5-6.) But her use of the term "soul" sometimes means a region of 
consciousness, "an interior world", and other times means an entity, a substance (notes Pike) like that Descartes assumed.

Now, the phenomenology of her experience would describe this "interior" soulregion, but the soul-substance would be ascribed from a metaphysical perspective external to the mystical experience. When Teresa subsequently reflects on what she experienced in prayer, we might infer, then she thinks in terms of soul-substance. This act of thinking — an act of metaphysical judgment - would "intend" not the soul-region, but the soul-substance. This metaphysical judgment may be distinguished from her experience of mystic union per se. In her theological judgment, then, she might form the belief that her soul-substance came into a special relationship with the great-soul-substance God (if that is what Teresa's actual theology holds). It is crucial here to distinguish phenomenology from ontology or metaphysics. Teresa's phenomenology characterizes her consciousness in the experience of mystic union. Her metaphysics, by contrast, characterizes her soul-substance and God and the personal relationship between them-all posited, of course, in acts of judgment articulating her theology, acts that have their own phenomenology.

Second, amplifying the experience of union, Pike quotes Jan van Ruysbroek's observation that the self is "melted and naughted" in the union (pp. 28-33). Bernard of Clairvaux, Pike finds, is more explicit, writing, "To lose yourself ... and to have no sense of yourself, to be emptied out of yourself and almost annihilated, belongs to heavenly not to human love." (p. 33) This loss of self, Pike notes, is part of "an experience in which the mystic makes no distinction between self and God." (p. 33) This sense of union sans self, or "union without distinction", Pike finds, is described in Blosius's report as an experience wherein the "loving soul ... sinks down into the abyss of divine love, ... it lives in God ... [and] in the infinite solitude and darkness of the godhead ..." (The quotation is on pp. 38-39.)

Here we find the phenomenology of loss-of-self describing consciousness as encountering "nothingness" or "abyss" but also as being immersed in "the godhead". Here, the phenomenology of mystic union seems to lead into a form of theologically informed consciousness wherein "the godhead" - the nature of God - is brought into the experience. As Pike dissects the experience of mystic union, then, we may separate the form of "pure" consciousness (the "abyss") from the more complex form of consciousness (mystic union) wherein the mystic draws in a theological conception of the "union" experienced, but all within the "pure" mystical experience.

Thus, drawing on our account of nibbanic consciousness, it seems the Christian mystic's experience of "union with God" can be factored into two levels of experience. First, there is basic nibbanic consciousness. The Christian mystics quoted and interpreted by Pike describe a form of consciousness as an experience of "nothingness", i.e. an experience sans self and sans object(s) — evidently the same form of consciousness experienced by mystics in other traditions, notably, as long described by Buddhist meditators. Second, in the Christian mystic's experience of union, there is a further level or factor of consciousness whereby this nibbanic consciousness is infused with a sense of transcendence and indeed, specifically, of God or the Godhead. This theistic element of defines the mystic's consciousness as if of "God": more specifically, as of "closeness to God", or of "union with God", or of "union without distinction" (rather than as if of "no-thing-ness"). That is, following Pike's analysis above, the theistic element may develop-temporally-in the 
different forms described. Then the complex form of consciousness achieved in mystical union, we would further specify, is itself structured into a nibbanic element and a further theistic element.

Now, the theistic element (in whichever form) should be seen as a moment, or dependent part, of the experience of mystic union. ${ }^{19}$ In Husserlian idiom, the theistic "moment" carries the noematic sense or intentional content $<$ God $>$ or $<$ union with God $>$. However, the nibbanic and theistic elements are distinct factors, "moments", in the whole experience. One form of consciousness is a pure, nibbanic consciousness, which may occur with no theistic factor. A more complex form of consciousness combines a theistic factor with a nibbanic factor. In that complex experience, the whole experience comprises two dependent parts, or moments: the one factor cannot occur without the other within that form of consciousness. Accordingly, following Pike's analysis, an experience of mystic union (as described by Teresa et al.) is a fusion of pure or nibbanic consciousness with a sense of transcendence and specifically a sense of "God". Where Pike's phenomenology defines a temporal progression through some three phases of Christian mystical consciousness, we are here defining two distinct levels of consciousness within one temporally bounded form of consciousness. This two-level structure informs each of the gradations of mystic union defined in Pike's phenomenology: respectively, experiences of "quiet", of "full union", of "rapture" in union, and of "union without distinction" - the one leading temporally into the next. Nibbanic consciousness is thus the foundation of each of the forms of mystical consciousness that Pike characterizes, an internal "moment" within each. ${ }^{20}$

Where there develops a temporal progression from pure, nibbanic consciousness into a sense of mystic union (involving God), the later theistic experience will typically depend on the prior nibbanic experience. Indeed, as Pike suggests, the later phase of mystical consciousness may depend on prior meditative thoughts, whereby the mystic's sense of "union without distinction" depends on a retention of the prior phase of consciousness bearing an explicit sense of union between self and God. The sense of "union without distinction" is thus more loaded than the simpler sense of "no-thing-ness" or "all-ness". Not only is the current phase of consciousness structured into current nibbanic and supra-nibbanic parts or "moments"; the current phase is also temporally structured by a "moment" of retention of the prior phase. (Compare Pike's analogy on pp. 162 ff.) ${ }^{21}$

\footnotetext{
${ }^{19}$ Here I assume the notion of "moment", or dependent part, used in Husserl's many works: see Smith (2007) on the varied uses of this notion. An independent part can exist apart from the whole: a bicycle wheel, for example, can be removed from the bicycle and so is an independent part of the bicycle. A dependent part cannot be separated from the whole (except in thought or "abstraction"): the yellow of this tennis ball, for instance, cannot exist apart from the ball itself (following the Aristotelian doctrine of "accidents").

${ }^{20}$ To be clear: an experience of pure consciousness can occur with no theistic element, in one form of meditative consciousness, whereas a theological judgment with theistic content can occur without a meditative consciousness of "no-thing-ness", but nibbanic and theistic moments are fused in an experience of mystic union.

${ }^{21}$ Zelinski has proposed this phenomenological analysis as a further explication of Pike's interesting analogy of being struck by a baseball: when you see it coming, your experience is different. Husserl elaborated the role of retention - as it were, very short-term memory within the stream of consciousnessin his famous studies of time-consciousness: Husserl (1893-1917/1991). Zelinski's analysis is developed in the present journal issue.
} 


\section{The Sense of Transcendence: Mindfulness, Sensation, Emotion}

Yet there is more to say about the sense of transcendence.

A more fine-grained account of the nibbanic level of consciousness, I should like to suggest, would further factor the base form itself into two levels. Most basic is simply a pure nibbanic awareness, featuring the sense of "nothingness" cum "wholeness", an awareness as if opening to further elements of consciousness. A sense of openness to experience is already a sense of "transcendence", prior to any theistic sense. Indeed, Husserl defines the "horizon" of an experience as a structure opening to further experience whose content is "indeterminate" yet defines the "transcendence" of whatever is indeterminately experienced. ${ }^{22}$ But, now, a second "moment" of nibbanic consciousness - as traditionally characterized - is a feature of awareness that may be described as a kind of sensation, a bodily-emotional awareness.

Buddhist meditation practice, following the Theravada ("Way of the Elders") tradition, features a form of meditation called vipassana, characterized as "mindfulness". ${ }^{23}$ Sitting in an appropriate position, the meditator attends to sensations of breath, bodily posture, passing thoughts, passing emotions, all with an increasing sense of equanimity, in a state of openness to experience. An emotional character comes to pervade the meditator's awareness, featuring conditions characterized as "divine" feeling (untethered by "I"), compassion, joy in others' good fortune, and equanimity. ${ }^{24}$ According to this phenomenology of mindfulness, what we are calling nibbanic consciousness has "moments" of both awareness and feeling: moments, dependent parts, of this base form of consciousness. Of course, the connotations of "nirvana" allude to this emotional sensation. Reflecting on this characterization of mindfulness-consciousness may help us understand Pike's dissection of the experience of mystic union-assuming some common forms of consciousness in both Buddhist and Christian contemplative experiences (while allowing differences in the experiences characterized).

Nibbanic consciousness, we now specify, comes in varieties of "pure" consciousness, with varieties of emotional sensation flavoring this base consciousness. In an expansive mode of mindfulness, then, nibbanic consciousness is ance an awareness and an emotional sensation: here lies the sense - indeed, the feelingof transcendence. This sense of transcendence, we should be reminded, does not present an "object" in consciousness: no "thing" is differentiated and "felt" as a particular being. (Following the modal model, we are addressing a "modality" of experience, not a "mode of presentation" of some object.)

\footnotetext{
22 This notion of "horizon" (Horizont) is used throughout Husserl's writings, not least Ideas I (Husserl 1913/1983). See Smith and McIntyre (1982) for a reconstruction of the notion (Chapters 5ff.).

${ }^{23}$ Smith and Novak (2003) offer a richly detailed account of various forms of mindfulness in vipassana practice, including subtle bodily awareness and attendant emotional awareness (pp. 74-87). Their account, on which I draw here, characterizes traditional Buddhist practices of mindfulness in a nuanced phenomenology (in effect, a phenomenography à la Pike). Goldstein (2003) characterizes contemporary practices of "mindfulness" in the vipassana tradition.

${ }^{24}$ See Smith and Novak (2003), p. 86, citing the Buddha's own characterizations. These mindfulness practices define an "emotional intelligence curriculum", the authors remark (p. 85), where emotions are experienced with clarity.
} 
Think of emotion as a kind of sensation: not visual or auditory but yet visceral, a sensation pervading one's being-emotion is indeed a bodily feeling, as William James already emphasized. ${ }^{25}$ Gradations of emotion lead into more intense feelings characterized as "nirvana" or perhaps "rapture". In this growing sensational nibbanic consciousness, a feeling pervades the sense of no-thing-ness. Still, no theistic or theological ideas are taking shape in this form of consciousness. A theistic moment may or may not then take shape, carrying the mystical experience into a sense of "the Godhead".

In this refined model, a philosophically loaded rendition of structure in theistic mystic union would say that the concept of God enters into the structured experience of union. We are accustomed to the role of concepts in everyday perception. For it is nearly a commonplace, following Kant and Husserl, that (for example) I cannot see-experience a visual consciousness of - "this yellow tennis ball" unless I have the concept <tennis ball> and even the concept <yellow>, where these conceptual structures are supported or "filled" (as Husserl put it) by appropriate sensations or "sensory data". The sensory and conceptual factors in my visual experience are moments, dependent parts, of the whole unified conscious visual experience. Similarly, it may be held, the mystic's experience of union with God involves both a form of "spiritual sensation" - the "sensation" of transcendenceand a form of conceptualization of "God" as what is experienced in this transcendent presence. Here we distinguish the "sensation" of transcendence from the conceptually loaded sense of "God" as such.

Indeed, Pike proposes just such an analysis of the mystic's experience of mystic union (see pages 161-166, noting the notion of "spiritual sensations"). I draw on the nibannic analysis above in the spirit of transposing Pike's vision into a more specific phenomenological framework. To elaborate this analysis, we invoke the notion of "intuition" in the technical sense.

Pike calls upon the Kantian notion of intuition (pp. 195ff), responding to the "construction theory" of Christian mystical experience (proposed by Steven Katz). Intuition (Anschauung) is direct awareness, the paradigm being perception. In an act of perception, say, where I see "this yellow tennis ball", my visual experience is a fusion of sensation and conceptualization. On the Kantian model, my sensory manifold is organized by concepts in a "synthesis" producing my visual presentation (Vorstellung) as of the ball-though (per Kant) my consciousness does not reach the thing-in-itself. Husserl follows suit, but offers a detailed theory of intentionality. On Husserl's analysis, my visual experience of "this yellow tennis ball" is a whole comprising unified moments of sensation (hyle) and interpretation (noesis) (Ideas I, $\S \S 84 \mathrm{ff}, 88 \mathrm{ff})$. The intentional or noematic content of my experience intuitionally presents "this ... ball" in my environment: "this" particular object "X", itself given "simpliciter" (\$131). In that way, my visual intuition grasps the thing (in) itself! That is the Husserlian picture (departing from prior theories such as the Kantian).

\footnotetext{
${ }^{25}$ Smith and Novak (2003) emphasize (pp. 81-82) how "body" and "mind" are experienced inextricably according to Buddhist (phenomenological) analysis. Husserl's phenomenological analysis of self, embodiment, and empathy also shows in detail how in everyday perception the structures of bodily awareness and consciousness of environing objects are fused: a recurrent theme in Ideas II (Husserl 1912/1989).
} 
Reflecting on this phenomenological structure in a simple visual experience, we may begin to appreciate just how distinctive is the phenomenological structure of the experience of the Christian mystic. Transposing Pike's phenomenography, we would say that the experience of mystic union is a direct awareness - an intuition - of God, of union with God. The mystic's base nibbanic consciousness is enriched with the intuitional form of the sense of transcendence: a "spiritual sensation" informed by a sense of "union with God".

\section{Intuition: Toward an Expansive Phenomenology of Mystic Union}

In the mystical experiences described in Pike's phenomenography, the mystic feels a connection - in intuition - with the transcendent, even with God. Yet her sense of self has "melted" away and so has her sense of discrete objects (such as a flower or tree or ball). The mystic describes a sense of "nothingness" and/or of the "oneness" of being, while yet expressing a sense of union or communion with "God". How might we understand the varied descriptions, appealing to "nothingness" on the one hand or to "oneness" or "allness" on the other, and somehow involving a sense of "God"? What could be more different, though the several mystics seem to be trying to describe a common form of experience?.

The experience of mystic union, as appraised by Pike, is a very special form of consciousness and indeed of intuition. Yet it differs importantly from everyday perception, on which the phenomenological model of "intuition" is based. There is a "spiritual sensation": at the very least a feeling of something impressing itself on the mystic's consciousness - not precisely as light or sound impresses itself on perceptual consciousness (as Hume put it, in the form of "impressions"), but somehow as if pressed from, well, transcendent reality. And in the Christian mystic's experience there is a further character: specifically a sense of "God". What exactly might this mean?.

The analogy with sensory perception may yet be of assistance. If I look out upon a scene where all is not well defined, what do I yet see? I look out on an expanse of the ocean (say, looking from where Nelson Pike himself lived). There is a bluish haze amid glistening light; no objects appear to me, impressing themselves upon my visual consciousness. Then, as if out of "nowhere", out of this bluish-haze of "nothingness", a sailboat appears, faintly yet quite definitely. It was "there" all along, impressing itself on me but not "appearing" in the light of my base nibbanic consciousness. But now, all of a sudden, "that misty sailboat" appears: the content $<$ that misty sailboat $>$ takes shape in my visual consciousness. My "soul-region", my "interior" region of nibbanic consciousness, is there all along, and now, of a sudden, it is in communion with this misty sailboat. A further moment of consciousness adds structure to this prior level of consciousness: "I see that misty sailboat" - now with a basic sense of myself as an embodied-subject in visual contact with an object in the great expanse before me, that is, my consciousness now is informed with a sensoryconceptual content $<$ I see that misty sailboat $>$.

If I am immersed in the tradition of Mahayana ("great raft" or "great vehicle") Buddhism, my consciousness in seeing the sailboat, at the initial level, is one of a certain sense of union between this basic visual consciousness and the boat 
appearing in my consciousness. ${ }^{26}$ Moreover, this consciousness is a form of intuition: the union is directly experienced as real-and is real so far as the experience is concerned. No Cartesian evil genius is deceiving me, and no Husserlian epoché is bracketing the reality of the experienced union. In intuition the experienced perspective is, as it were, both internal and external: as from the subjective perspective ("now here in this very experience") and as from the objective perspective ("that sailboat actually now there before me and affecting my eyes"). By analogy: If I am the mystic, my consciousness of mystic union is one of a certain sense of union between "this" base nibbanic consciousness and the transcendent being experienced therein - though the traditional Buddhist will not take this being as a substance with specific attributes such as omniscience, omnipotence, personhood, and so on, that is, along the lines of Christian theology.

Consider, accordingly, the perspective of Teresa, or one of the other mystics whose experience Pike addresses. From the first-person perspective in my perception: in seeing the sailboat, I experience a sense of union between my visual consciousness and the boat appearing in the bluish expanse-a form of visual intuition just as described above. Now switch to the perspective of the mystic who, like Teresa, is immersed in the tradition of Christian theology. From the first-person perspective where "I" am the mystic: in experiencing mystic union, "I" (= "this soulregion") experience a sense of union between "this" basic consciousness (= "this interior castle") and "this" transcendent being felt (with "spiritual sensation") therein (in "union" with "this consciousness") — "this Godhead", or "God", appearing now with attributes of "His" (or for Teresa "Her"!) greatness.

Has the mystic directly experienced "this Godhead", in a form of transcendent intuition? Or has her consciousness moved into a more complex level of mystical experience, wherein a certain theological conception shapes the experience of "union"? Or has the mystic's experience begun to lead into a reflective mode? Has she taken a step into phenomenological reflection on the nature of this intuitional experience? Has she taken a further step into a separate act of judgment about her experience, where her metaphysical beliefs about God shape her judgment about what she is actually experiencing in this experience of "union"? What is internal to her experience of "union", and what is external to the experience?

Pike considers a similar distinction of levels that may be discerned within the mystic's experience of union - in thought experiments the reader should experience in Pike's own phenomenographic prose (pp. 162-166). With the form of "nibbanic" consciousness in mind, I close with a nod to the intriguing issue of how a Buddhist and a Christian experience of transcendence compare (at some appropriate level!). As it happens, Daniel Zelinski has worked explicitly on the issue of commonality in phenomenology between two articulate mystics: the $13^{\text {th }}$ century Japanese Zen

\footnotetext{
${ }^{26}$ Smith and Novak (2003) characterize the "great raft" of Buddhist practice ferrying more people (not only the few) across life's sea (p. 65). The point here is that in Buddhist experience meditation itself may be informed by a view of the very practice itself, the Mahayana view as opposed to the Theravada view ("the way of the elders", the few). Similarly, Christian contemplative experience is informed by a theological view of the experience itself, that is, in the cases Pike analyzes. The "great raft" metaphor may suggest, in the present context, that meditators in different traditions experience a basic level of nibbanic consciousness, a level that is open to further, differentiating elements of consciousness - as we are here discussing.
} 
Buddhist mystic, Dogen, and the $14^{\text {th }}$ century German Christian mystic, Meister Eckhart. ${ }^{27}$ Apropos the theology at stake, Pike notes that Eckhart was "roundly condemned by the pope" for assuming metaphysical monism in describing mystic union as an "ineffable experience" wherein "I am God" (p. 180, addressing R. C. Zaehner's account of theistic mystical experience). With that note I recommend turning to Zelinski's reading of these issues and Pike's results.

Acknowledgement I am thankful to Nelson Pike for his book, and for all he did for philosophy at UC Irvine, and for his role in bringing me to UCI these many years ago. Now I should like to express gratitude to colleagues who have been most helpful in addressing the remarkable phenomena here discussed: Dan Zelinski, for discussions and comments on this paper itself; Phil Walsh, for discussions of relevant issues; Roger Walsh, for his perspective and encouragement along my way; the colleagues and audience at the Nelson Pike Conference at UCI on December 11, 2010. In a special note, may I express appreciation for the perspective, wisdom, and life-work of Huston Smith-ever so briefly my colleague at MIT, long before I came to learn from his remarkable writings.

Open Access This article is distributed under the terms of the Creative Commons Attribution Noncommercial License which permits any noncommercial use, distribution, and reproduction in any medium, provided the original author(s) and source are credited.

\section{References}

Albahari, M. (2006). Analytical Buddhism: The two-tiered illusion of self. New York: Palgrave Macmillan. Forman, R. K. C. (Ed.) (1990). The problem of pure consciousness: Mysticism and philosophy. Oxford and New York: Oxford University Press.

Goldstein, J. (2003). Insight meditation: The practice of freedom. Boston and London: Shambhala. First edition, 1993.

Gupta, B. (2003). Cit: Consciousness. Oxford: Oxford University Press.

Husserl, E. (1912/1989). Ideas II: Ideas pertaining to a Pure Phenomenology and to a Phenomenological Philosophy, Second Book: Studies in the Phenomenology of Constitution. Translated by Richard Rojcewicz and André Schuwer. Dordrecht and Boston: Kluwer Academic Publishers, 1989. Original manuscript dating from 1912, posthumously published in German in 1952.

Husserl, E. (1913/1983). Ideas I: Ideas pertaining to a pure phenomenology and a phenomenological philosophy, first book: General introduction to pure phenomenology. Translated by Fred Kersten. Dordrecht and Boston: Kluwer Academic Publishers. (Now: New York: Springer.) 1983. German original 1913.

Husserl, E. (1893-1917/1991). On the phenomenology of the consciousness of internal time (1893-1917). Translated by John Barnett Brough. Dordrecht and Boston: Kluwer Academic Publishers. (Now: New York: Springer.) Lecture manuscripts from 1893 to 1917.

Kriegel, U., \& Wiliford, K. (Eds). (2006). Self-representational approaches to consciousness. Cambridge, Massachusetts: MIT.

MacKenzie, M. D. (2007). The illumination of consciousness: approaches to self-awareness in the Indian and Western Traditions. Philosophy East \& West, 57(1), 40-62.

Mohanty, J. N. (1993). In P. Bilimoria (Ed.), Essays on Indian philosophy. Oxford, New York, New Delhi: Oxford University Press.

Pike, N. (1992). Mystic union: An essay in the phenomenology of mysticism. Ithaca and London: Cornell University Press.

Smith, D. W., \& McIntyre, R. (1982). Husserl and intentionality: A study of mind, meaning, and language. Dordrecth and Boston: D. Reidel Publishing Company, now Springer.

\footnotetext{
${ }^{27}$ See Zelinski (1997). Zelinski's dissertation was written under joint supervision by Nelson Pike and myself. There was input also from Roger Walsh, a neuroscientist and psychiatrist with long experience in the practice and study of meditation. This was the last dissertation Professor Pike worked on in his long career, and I should like to record how greatly appreciated was Nelson's work with graduate students.
} 
Smith, D. W. (1986). The structure of (Self-) consciousness. Topoi, 5(2), 149-156.

Smith, D. W. (1989). The circle of acquaintance: Perception, consciousness, and empathy. Dordrecht and Boston: Kluwer Academic Publishers. Now New York: Springer.

Smith, D. W. (2004). Return to consciousness. In D. W. Smith (Ed.), Mind world: Essays in phenomenology and ontology (pp. 76-121). Cambridge and New York: Cambridge University Press.

Smith, D. W. (2005). Consciousness with reflexive content. In D. W. Smith \& A. L. Thomasson (Eds.), Phenomenology and philosophy of mind (pp. 93-114). Oxford and New York: Oxford University Press.

Smith, D. W. (2007). Husserl. New York and London: Routledge.

Smith, H., \& Novak, P. (2003). Buddhism: A concise introduction. New York: HarperCollins Publishers.

Walsh, R., \& Vaughn, F. (Ed.) (1993). Paths beyond ego: The transpersonal vision. Los Angeles: Jeremy P. Tarcher/Perigee, the Putnam Publishing Group.

Zelinski, D. (1997). The meaning of mystical being: An inquiry into phenomenological and moral aspects of the ways of life advocated by Dogen Zenji and Meister Eckhart. Doctoral dissertation. Irvine: University of California, Irvine. 